\section{Tool Curation Behavior, and Group Range Estimates: A Model-Based Exploration}

Lithic Transport Patterns,

\author{
ANDREW WHITE (1)
}

RESEARCH ARTICLE

\section{] $\mathrm{u}$ [ubiquity press}

CORRESPONDING AUTHOR:

\section{Andrew White}

University of Illinois, US

aaw7@illinois.edu

\section{KEYWORDS:}

hunter-gatherers; lithic transport; mobility; lithic technology; agent-based model

\section{TO CITE THIS ARTICLE:}

White, A. 2021. Lithic Transport Patterns, Tool Curation Behavior, and Group Range Estimates: A ModelBased Exploration. Journal of Computer Applications in Archaeology, 4(1):254-273.DOI: https://doi.org/10.5334/jcaa.82 


\section{INTRODUCTION}

Information about the transport of lithic artifacts is a common component of inferences about the mobility of prehistoric hunter-gatherer societies (e.g., see Arrizabalaga et al. 2014; Burke 2006; Donadei 2019; Ellis 2011; Kusimba and Kusimba 2003; Meltzer 1984; Preston 2009; Tomasso and Porraz 2016). Because of a presumed close relationships between group mobility and stone tool transport (largely following Binford 1979:261), changes in stone transport distances are often attributed to changes in group mobility behaviors (e.g., Koldehoff and Loebel 2009; Sassaman et al. 1988; Smallwood et al. 2015; White 2012, 2014), and zones of raw material transport are sometimes taken to outline the territorial ranges of more-or-less distinct social units (e.g., Carr 2005; Daniel 2001; Jennings 2008b; Preston and Kador 2018).

This paper uses a model-based approach to systematically explore how technological changes affect the accuracy with which transport distances reflect the scale of group mobility. Specifically, I use an agentbased model to explore how variables affecting tool kit utility (use-life, inventory size, and frequency of use) 'map up' to large-scale transport patterns in a model system where seasonal dispersion and aggregation are centered on a lithic source. This builds a baseline for understanding how lithic transport patterns are linked to technological behaviors in a simple hypothetical lithic procurement system.

My impetus for performing this work was to better understand the Paleoindian (ca. 13,400-11,500 cal YBP) and Early Archaic (ca. 11,500-9000 cal YBP) societies of the Eastern Woodlands (an area encompassing the temperate regions of the United States and Canada east of the Mississippi River). These societies utilized wellmade, 'curated' hafted bifaces (which I also refer to as 'projectile points' or simply 'points') that were frequently discarded significant distances from the sources of the stone used to make them. Early Paleoindian fluted points (e.g., Clovis) were routinely transported several hundred kilometers from the locations of the raw materials used in their manufacture (e.g., Ellis 2011; Carr 2011; Koldehoff and Loebel 2009; Loebel 2005; Mullet 2009; Shott 1986; Simons et al. 1984; Smallwood et al. 2015; Tankersley 1989), and examples of transport distances on the order of 600-700 km and even $1400 \mathrm{~km}$ have been reported (e.g., Brose 1994; Koldehoff and Loebel 2009; Tankersley 1994). Lower transport distances during the Middle/Late Paleoindian periods are followed by increases during the Early Archaic period (White 2012, 2014). Although there is clearly regional variation, this "high-lower-higher" pattern is discernible in multiple datasets from across the Eastern Woodlands. Changes in the transport patterns of these tools were often accompanied by changes in the manufacture, design, use, and discard of the stone tools themselves (e.g., Cantin 2000; Tune 2016; White 2014, 2019), posing the question of if and how parallel changes in curation behavior and transport distance might be related to one another.

This work adds to the growing number of studies using computational modeling to aid in the interpretation of archaeological assemblages. Studies exploring aspects of lithic raw material usage and transport patterns (Barton and Riel-Salvatore 2014; Brantingham 2003; Pop 2016) and lithic assemblage composition (Coco et al. 2020; Davies et al. 2018; Gravel-Miguel et al. 2021; Barton and Riel-Salvatore 2014; Brantingham 2003; Pop 2016), for example, demonstrate the utility of computational models for understanding the complex behavioral factors that contribute to the lithic data we are attempting to interpret. Although these studies all consider relationships between movement/mobility and archaeological residues, none directly considers questions about how technological changes related to tool curation behaviors might or might not affect the suitability of using the scales of lithic transport as a proxy for the scales of group mobility. This work seeks to contribute to ongoing 'bottom up' modeling studies that help us build theory about how human behaviors produce archaeological patterns by addressing that question in a simple model world with clearly defined scenarios.

I first discuss the experimental, ethnographic, and archaeological bases for setting value ranges for the model parameters representing stone tool use and discard behaviors. I then describe the model and present the results of experimentation where the values of parameters are systematically varied in order to investigate their effects on patterns of stone tool transport, holding mobility behaviors constant and collecting data on the discard of stone tools. I briefly discuss the model results in relation to the contrasting patterns of transport distance and tool maintenance/use that characterize the Early and Late Paleoindian periods. While the work presented here was performed with the specific case of these particular foraging societies in mind, the general observations derived from the model results are applicable to many situations with similar sets of overlapping technological/mobility issues.

\section{ESTIMATING PARAMETERS OF TOOL USE AND DISCARD}

Parameters of tool use are logically related to the distances tools are transported by mobile societies prior to discard. Other things being equal, tools that remain in an individual's tool kit longer have the potential to be moved greater distances. If movement away from the location of manufacture is unidirectional, sourceto-discard distances will increase as tools remain in the inventory longer. Three factors in combination affect 
how long individual tools remain in an inventory: use-life, inventory size, and frequency of use.

\subsection{USE-LIFE}

The use-life of a tool describes the duration of the tool's service life (Schiffer 1987, 1995; Shott and Ballenger 2007). Use-life and curation (how much utility is extracted from a tool prior to discard) often covary: highly curated tools tend to have longer use-lives (see Shott 1996; Shott and Ballenger 2007). Because lithic technology is inherently reductive, each reworking of a tool (e.g., for the purposes of repair or resharpening) decreases its remaining utility. Other things being equal, tools with longer use-lives will tend to be moved a greater number of times across the landscape prior to discard.

Experimental studies suggest that the use-lives of many stone tools may have been relatively short. For hafted bifaces used as knives, saws, or scrapers, we can presume that utility is mainly lost through attrition: removal of material to rejuvenate a dulled edge leaves less potential utility (see Shott and Ballenger 2007). Goodyear's (1974:26-30) experiment suggested that a typical Dalton point being used as a serrated knife could be resharpened perhaps 2-4 times before it was no longer useful as a knife. The fourteen Kirk points in Wilkinson's (2019) experimental assemblage were bifacially resharpened 8-11 times (mean 9.3) before being classified as 'exhausted'.

In addition to utility being lost through attrition, points that served as projectile tips were also subject to failure through catastrophic breakage (see Shott and Sillitoe 2004). Experimental studies make clear that stone hafted bifaces are fragile objects when employed as projectile tips: many break on the first impact and few survive multiple impacts (e.g., Cheshier and Kelly 2006; Titmus and Woods 1986:43). In the experimental data assembled by Shott (2002), no points survived more than eight firings.

Given what we know about hafted bifaces from experimental and archaeological data, it is safe to say that they were often designed for multiple uses (resharpening episodes and/or projectile firings) but were probably often exhausted in ten uses or less. A range of $1-10$ is used in the experiments below.

\subsection{INVENTORY SIZE}

Inventory size - the number of functional tools that a person keeps at any one time - affects the total utility of a tool kit. Assuming that tool use-life and frequency of use remain constant, an inventory with twice as many tools contains twice as much utility and would be expected to last twice as long.

It is difficult to estimate the number of points (or preforms that could be made into points) that an individual hunter-gatherer might have transported in a personal inventory. It seems reasonable to assume that an individual's inventory was calibrated to satisfy expected needs for some more-or-less specific period of time, and it seems unlikely that weight was a major constraint. If we presume a mean mass of $25 \mathrm{~g}$ per point, an inventory of 50 points would weigh about a kilogram (about the same as a liter of water), a small percentage of the $35 \mathrm{~kg}$ of gear that might comprise a 'typical' hunter-gatherer load (see Speth 2018:175-186).

Archaeological caches - intentionally buried deposits of materials - may provide some insight into the sizes of tool inventories. Caches of 'active' gear represent assemblages of equipment in regular use at the time of deposition (in contrast to caches of 'passive' gear or stockpiles of material intended to be retrieved in the future) (see Bamforth 2009; Deller, Ellis \& Keron 2009). Deller, Ellis \& Keron (2009:372) argued that the Late Paleoindian deposit at the Crowfield site (Ontario) containing 30 fluted points and preforms was 'a functioning, transported, tool kit' that 'most likely represent an individual's belongings'. Other Late Pleistocene/Early Holocene caches that could represent deposits of 'active' gear also contained large assemblages of projectile points (see Bamforth 2009; Deller et al. 2009). Smaller point assemblages have been documented from Late Paleoindian deposits probably associated with human burials (Morse 1977) and an Early Archaic cache (Goodyear et al. 2004; White 2016). A range of $1-50$ is used in the experiments described below.

\subsection{FREQUENCY OF USE}

Frequency of use refers to how often a tool is used for a task that removes a portion of the remaining utility. While multifunctional tools like hafted bifaces were certainly a part of everyday life and would have been used regularly, estimating frequency of use in quantitative terms is difficult. If points were used mainly as tips of projectile weapons, their frequency of use would depend strongly on the frequency of hunting. If points were used for a wider variety of tasks, their frequency of use would be greater.

Several researchers have estimated that an individual hunter-gatherer might use between 10 and $50 \mathrm{~kg}$ of stone material per year (see Speth 2018), only a percentage of which would be used in the form of projectile points. Bifaces (including both finished fluted points and performs) accounted for between $4 \%$ and $17 \%$ of Paleoindian assemblages by weight at the Leavitt (Shott 1993), Fisher (Storck 1997), and 11Ls981 (Loebel 2005) sites. If assumed that $15 \%$ of a hunter-gatherer's annual $10 \mathrm{~kg}$ supply of stone was used for projectile points and other bifacial tools, we can estimate that 60 points weighing 25 grams each were produced per year. If those points were used an average of three times before being exhausted, we can calculate a mean of 3.5 uses per week. If $30 \mathrm{~kg}$ of total of stone was used, the mean goes up to 10.4 uses per week. 
Although these estimates are firmly in the range of guesswork they do not seem unreasonable for modeling purposes. A range of 1-10 uses per week is used in the experiments described below.

\section{A COMPUTATIONAL MODEL FOR ANALYSIS OF LITHIC TRANSPORT PATTERNS}

Computational modeling offers an avenue for understanding how tool use/discard behaviors are related to tool transport patterns. Computational modeling can be used to systematically explore how changes in 'rules' affecting the creation, use, and discard of stone tools at the level of individual persons affect patterns of stone tool transport like those we can observe archaeologically.

The Style_Net_01 model is an agent-based model built using Repast Simphony and written in the Java programming language (see www.repast.sourceforge.net). A schematic illustration of the basic parts and operations of the model is shown in Figure 1. Geographic space is an orthogonal grid of $10 \mathrm{~km} \times 10 \mathrm{~km}$ cells. Time passes in discrete steps with each step representing one week. The model has four main 'levels:' artifact, person, group, and system. Each agent in the world represents an individual person. Persons make, use, and discard artifacts. Persons travel in groups within the geographic space of the model.

The groups in the model represent traveling, coresidential groupings of persons that make tools. Among mobile hunter-gatherers, the reported size of ethnographically-documented foraging groups at their most dispersed varies between 5 and 35, with a single reported case of 1 (Binford 2001:Table 8.01, see White 2012:Figure 2.3A). Because the current iteration of this model is only intended as a vehicle for the analysis of lithic use/discard behaviors, persons in the model represent the fraction of a foraging group (perhaps one quarter to one third) that might be reasonably expected to be making and using formal stone tools such as projectile points. Group size stays constant because there is no birth or death and persons cannot move between groups. Thus, in the experiments discussed here, person and group behaviors are essentially the same (persons were built into the model to allow heterogeneity at that level in future work with the model). At the beginning of each run, the model creates 10 groups of 6 that report to a single aggregation site.

Groups in the model move at every step. This is at the high end of the range for frequency of residential movement among ethnographically-

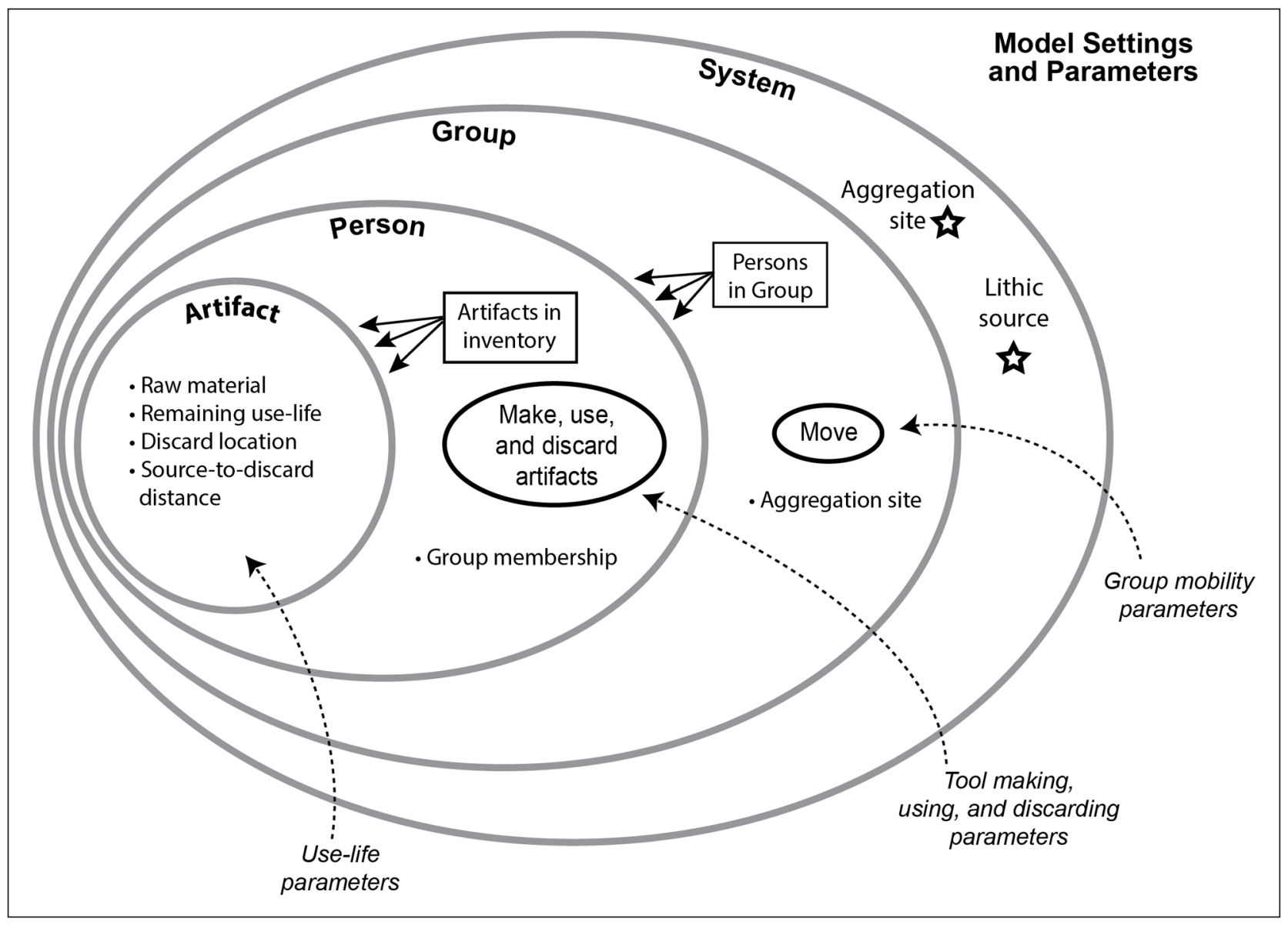

Figure 1 Schematic of the Style_Net_01 model. 
observed foraging groups (Binford 2001; Kelly 1995; see White 2012:Figure 2.2). The scale of movement is controlled by a model-level parameter (moveDistance, or $\mathrm{mD}$ ) that specifies how many cells a group moves each step. Among ethnographic hunter-gatherers, the average distance of residential movement varies from less than $5 \mathrm{~km}$ to over $70 \mathrm{~km}$, with total (annual) distances varying from 0 to about $800 \mathrm{~km}$ (see White 2012:Figures 2.2A and 2.2B). The highest total distances are associated with groups making a relatively small number of long moves and groups making a relatively high number of short moves.

The movements of groups in the model occur in a seasonal pattern of aggregation and dispersal, with all groups coalescing at an aggregation site at the end of the yearly cycle. Periodic aggregation of regional populations is a common feature of hunter-gatherer settlement systems (Birdsell 1968:234; Conkey 1980; Kelly 1995; Walthall 1998), with aggregations of 100300 people commonly reported among mobile huntergatherers (see White 2012:Figure 2.3C). A similar, general pattern of seasonal aggregation and dispersal has been inferred by many researchers for the Paleoindian and Early Archaic societies of eastern North America (e.g., Anderson and Hanson 1988; Daniel 2001; Walthall 1998). In future work with the model, persons will be able to move between groups at aggregation sites, simulating a different mechanism of stone tool transport.

The direction of group movement in the model is controlled by a seasonal clock: groups move away from the aggregation site during the first 24 weeks of the year and toward the aggregation site during the remainder of the year. Groups not at the aggregation site by the last step of the year are moved to it automatically. Because each of the ten groups in these runs represents a coresidential foraging group of about 20 people (with six tool users per group), the total population of the band during aggregation is 200 people.

Each time a group moves, a list is constructed of all the unoccupied cells that are moveDistance away from the group's current location and in the correct direction of movement (i.e., farther from or closer to the aggregation site, depending on the season). One of those cells is randomly selected to be the group's new location. The maximum straight line distance that groups reached from the aggregation site is recorded for each run. Because groups can move diagonal to the XY axis of the spatial world, the maximum possible range will be equal to the hypotenuse of a square with sides of moveDistance * (season1Ticks - 1). If the value of moveDistance is 1 (10 km), for example, a group that moves diagonally away from the aggregation site for 24 steps will reach a straight line distance of 33.9 cells $(339 \mathrm{~km})$ from the aggregation site, compared to 24 cells (240) $\mathrm{km}$ for a group that moves along the $X$ or $Y$ axis.
A lithic source (representing a geographically-specific, recognizable source of stone for tools) is placed in the world at the location of the aggregation site. This simulates the simple conditions of an explicitly 'lithiccentric' model of group dispersal and aggregation where lithic procurement is closely linked to annual group mobility. This arrangement represents a 'tethered' procurement/mobility system similar to that often suggested for Paleoindian and Early Archaic societies, a characterization that can largely be traced to the work in the late 1970s and early 1980s that connected stone tool transport among hunter-gatherers to residential mobility (see Binford 1979:261; Custer et al. 1983; Gardner 1974:41, 1983; Goodyear 1979). My choice to represent a 'tethered' model of lithic procurement does not constitute an argument that such an arrangement was used by Paleoindian and Early Archaic societies. It is, rather, a logical first step to explore how lithic transport patterns are linked to tool manufacture, use, and discard behaviors in perhaps the simplest case of a procurement system like those commonly supposed to have been present among the early hunter-gatherers of the Eastern Woodlands.

The creation, use, and discard of artifacts is controlled by several parameters that specify how many tools each person carries in a personal inventory (toolInventorysize, or tIS), how many times each tool can be used before it is discarded (toolUseLife, or tUL), and the number of tool uses that occur each step for each person (toolUsesPerStep, or tUPS). For purposes of analysis, these three parameters were combined into a single variable called the Retention Index (RI):

\section{Retention Index = toolInventorySize * toolUseLifel toolUsesPerStep}

The RI divides the total utility (i.e., total number of potential uses) in a fully-stocked, brand new tool kit by the amount of that utility that will be spent each step. If the toolinventorysize is 10 and each tool has a toolUseLife of 2, there are a maximum of 20 total uses in a tool kit (i.e., if all the tools are unused). Under conditions where 5 uses are expended each step, the RI would be 4. If toolUselife or toolinventorysize is halved but toolUsesPerStep remains constant, the RI will be halved. The lower the value of the RI, the greater proportion of the toolkit's utility is expended each step and the faster that tools in the inventory will be used up and discarded. Thus the RI is a metric for the rate of discard.

New tools are made as required to maintain the specified tool inventory size. A person within range of the lithic source will utilize the source when making new tools. The value of a model-level parameter (personalMobilityRadius, or $\mathrm{PMR}$ ) controls the radius which a person can utilize to access the lithic source. For 
the experiments discussed below, the value of $p M R$ was always set to 1 (i.e., a person can range $10 \mathrm{~km}$ from the group). Because aggregation occurs at the lithic source, persons can only access the lithic source during that time of the year. No other aspects of personal mobility are incorporated into the runs discussed here (i.e., persons cannot move between groups). Tools are also manufactured as needed when a person is not within range of the lithic source, but those tools are made from some other, non-source, material.

Two additional model-level parameters affect the production and discard of tools when a person is within range of the lithic source. First, the parameter productionFactor $(p F)$ allows for 'over-production' of tools when a person can exploit the lithic source. When the value of productionfactor is set to 1 , persons make tools to replenish their tool kits in the same way they do when they are not near the lithic source. When the value of productionFactor is greater than 1, the desired toolinventorysize is increased so that the person will produce more tools. If productionFactor $=2$, for example, the person will produce enough tools to create a tool inventory with a size of $2 x$ toolInventorysize. Second, the Boolean parameter replacement $(r$ ) controls whether or not a person discards all the used tools in that person's inventory when in proximity to a lithic source. If all used artifacts are discarded, a person will end up leaving the aggregation site/lithic source with a tool inventory composed entirely of artifacts made from the lithic source. In combination, these two parameters can be used to simulate a situation where people 'gear up' when in close proximity to a lithic source, beginning their yearly round with a large, new tool inventory made exclusively from a single raw material.

At each step during a run, the model initiates a sequence of actions that: (1) move the groups and persons through space; (2) cause persons to check their proximity to the lithic source, create new tools and add them to their inventories, use tools in their inventories, and discard tools that have no remaining use-life. The model calculates the distance between the lithic source and the discard location if the tool was made from the lithic source. The model only collects data about discarded tools during a data collection period (T1), allowing model societies to get past start-up conditions and settle into their regular behavior before data are collected. When data collection is on, the model collects a random 50 percent sample of the tools that are discarded (a 50 percent sample was chosen to decrease data processing time). Those tools form the basis of the summary data about transport patterns.

Further details of the model's design and operation, as well as the raw code, are available online at OpenABM. org (https://www.comses.net/codebases/dcb8e3db-fd0a-41f7a6ae-9c16118440ac/releases/1.0.0/).

\section{EXPERIMENTS AND RESULTS}

Four batches of experiments were performed to systematically investigate the relationships between the 'range' of the groups in the model, the tool creation, use, and discard behaviors of the persons in the model, and the lithic transport patterns that emerged from the combination of group mobility and person-level behaviors (Table 1). Model runs lasted 26,000 steps (i.e., 500 'years'). Data on discarded tools were recorded during the last 100 years of each run (T1). Settings for the key parameters related to tool use and discard (toolInventorySize, toolUselife, and toolUsesPerStep) were varied randomly in Experiments $1-3$ to generate information about how combinations of variables are related to transport distance.

\subsection{EXPERIMENT 1}

Experiment 1 was designed to examine the relationships between the RI and transport distances. The setting for toolInventorysize was varied randomly between 1 and 50 and the settings for toolUseLife and toolUsesPerStep were varied randomly between 1 and 10, producing RI values ranging from 1 to 500. Note that these parameters are varied per run: their values apply equally to all persons and groups in each run. Five different settings of moveDistance were used (Table 1 and Figure 2). Table 2 shows the maximum possible group range and the minimum, maximum, and mean group ranges actually experienced by groups for each mobility setting.

Figure 3 shows the maximum transport distance plotted against the RI for each batch of runs. The relationships are clearly nonlinear. The pattern is the same at each of the mobility settings because only the scale of mobility (rather than the frequency) differs.

Because the actual distance that groups moved was always less than the maximum possible group range, the ratio of the maximum transport distance (the maximum source-to-discard distance) to the actual maximum group range (the maximum distance that any group moved from the aggregation site) expresses the percentage of the actual range that was directly reflected by tool transport patterns. This ratio (\%MaxRange) was calculated for each run, allowing all the results from all the runs in Experiment 1 to be plotted together.

The nonlinearity of the relationship between the RI and \%MaxRange is clear when displayed on a log axis (Figure 4). In runs with an RI > 14, maximum transport distance was generally $90 \%$ or more of the maximum group range. In runs with an $\mathrm{RI}<1$, conversely, maximum transport distance never reflected more than $16 \%$ of the maximum group range. The high (>14) RI values that characterize runs with relatively good fidelity between maximum transport range and maximum group range are the result of tool use/discard systems that combine 


\begin{tabular}{|c|c|c|c|c|c|c|c|c|}
\hline EXPERIMENT & N RUNS & MD & PMR & TIS & TUL & TUPS & $P F$ & $R$ \\
\hline $1 a$ & 2,000 & 1 & 1 & 1-50 (vary randomly) & 1-10 (vary randomly) & 1-10 (vary randomly) & 1 & Off \\
\hline $1 b$ & 2,000 & 2 & 1 & 1-50 (vary randomly) & 1-10 (vary randomly) & 1-10 (vary randomly) & 1 & Off \\
\hline $1 c$ & 2,000 & 3 & 1 & 1-50 (vary randomly) & 1-10 (vary randomly) & 1-10 (vary randomly) & 1 & Off \\
\hline $1 d$ & 2,000 & 4 & 1 & 1-50 (vary randomly) & 1-10 (vary randomly) & 1-10 (vary randomly) & 1 & Off \\
\hline $1 e$ & 2,000 & 5 & 1 & 1-50 (vary randomly) & 1-10 (vary randomly) & 1-10 (vary randomly) & 1 & Off \\
\hline 2 & 100,000 & 2 & 1 & 1-50 (vary randomly) & 1-10 (vary randomly) & 1-10 (vary randomly) & 1 & Off \\
\hline $3 a$ & 100,000 & 2 & 1 & 1-50 (vary randomly) & 1-10 (vary randomly) & 1-10 (vary randomly) & 1 & On \\
\hline $3 b$ & 100,000 & 2 & 1 & 1-10 (vary randomly) & 1-10 (vary randomly) & 1-10 (vary randomly) & 2 & Off \\
\hline $3 c$ & 100,000 & 2 & 1 & 1-10 (vary randomly) & 1-10 (vary randomly) & 1-10 (vary randomly) & 2 & On \\
\hline $4 a$ & 20 & 2 & 1 & 2 & 4 & 9 & 1 & Off \\
\hline $4 b$ & 20 & 2 & 1 & 3 & 7 & 9 & 1 & Off \\
\hline $4 c$ & 20 & 2 & 1 & 12 & 3 & 10 & 1 & Off \\
\hline $4 d$ & 20 & 2 & 1 & 26 & 2 & 9 & 1 & Off \\
\hline $4 e$ & 20 & 2 & 1 & 11 & 8 & 5 & 1 & Off \\
\hline $4 f$ & 20 & 2 & 1 & 27 & 9 & 3 & 1 & Off \\
\hline $4 \mathrm{~g}$ & 20 & 2 & 1 & 2 & 4 & 9 & 2 & On \\
\hline $4 h$ & 20 & 2 & 1 & 3 & 7 & 9 & 2 & On \\
\hline $4 i$ & 20 & 2 & 1 & 12 & 3 & 10 & 2 & On \\
\hline $4 j$ & 20 & 2 & 1 & 26 & 2 & 9 & 2 & On \\
\hline $4 k$ & 20 & 2 & 1 & 11 & 8 & 5 & 2 & On \\
\hline 41 & 20 & 2 & 1 & 27 & 9 & 3 & 2 & On \\
\hline
\end{tabular}

Table 1 Settings used in model experiments ( $\mathrm{mD}$ = moveDistance; $p M R=$ personalMobilityRange; $t I S$ = toolInventorySize; tUL = toolUseLife; tUP = toolUsesPerStep; $p F=$ productionFactor; $r$ = replacement).

\begin{tabular}{|c|c|c|c|c|c|}
\hline \multirow[t]{2}{*}{ EXPERIMENT } & \multirow[t]{2}{*}{ MOVEDISTANCE (CELLS) } & \multirow{2}{*}{$\begin{array}{l}\text { MAXIMUM POSSIBLE } \\
\text { GROUP RANGE (KM) }\end{array}$} & \multicolumn{3}{|c|}{ ACTUAL MAXIMUM GROUP RANGE (KM) } \\
\hline & & & MINIMUM & MAXIMUM & MEAN \\
\hline $1 a$ & 1 & 339 & 246 & 298 & 263 \\
\hline $1 b$ & 2 & 671 & 415 & 503 & 442 \\
\hline $1 c$ & 3 & 1018 & 575 & 708 & 620 \\
\hline $1 d$ & 4 & 1357 & 738 & 925 & 797 \\
\hline 1e & 5 & 1697 & 908 & 1139 & 973 \\
\hline
\end{tabular}

Table 2 Actual ranges travelled by groups in Experiment 1.

long tool use-life and/or large tool inventory size with a low number of uses per step. When tools last a long time, individual tools will tend to stay in the inventory longer and therefore have a greater chance of being moved farther prior to being discarded. The low $(<1)$ RI values are produced in the context of systems with short tool use-lives and/or small tool inventory sizes and a high number of uses per step: tool inventories are cycled rapidly and individual tools have a lower chance of being moved long distances prior to discard.

While the association between RI and maximum transport distance is clear at the poles of the distribution it is quite loose in the 'middle range' between 1 and 14 (see Figure 4). In runs with an RI of 5, for example, maximum transport distance reflected anywhere between $21 \%$ and $99 \%$ of the maximum group range. Because group mobility settings remained constant, the distribution of outcomes is solely the result of different combinations of tool inventory size, tool use-life, and uses per step. Of the three use/discard parameters, the value of inventory size is most strongly correlated with the resulting \%MaxRange in the 'middle range' of the RI (Figure $5 ; r=0.70)$, followed by use-life $(r=-0.32)$. Uses per step is effectively uncorrelated with \%MaxRange 


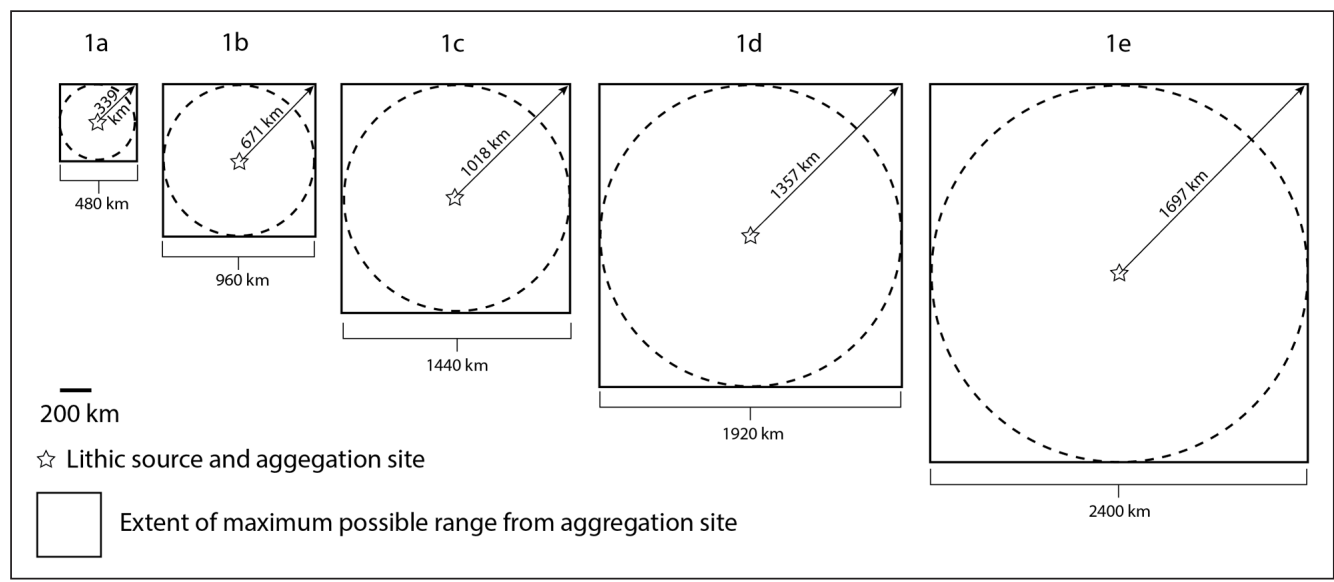

Figure 2 Mobility settings used in Experiment 1.

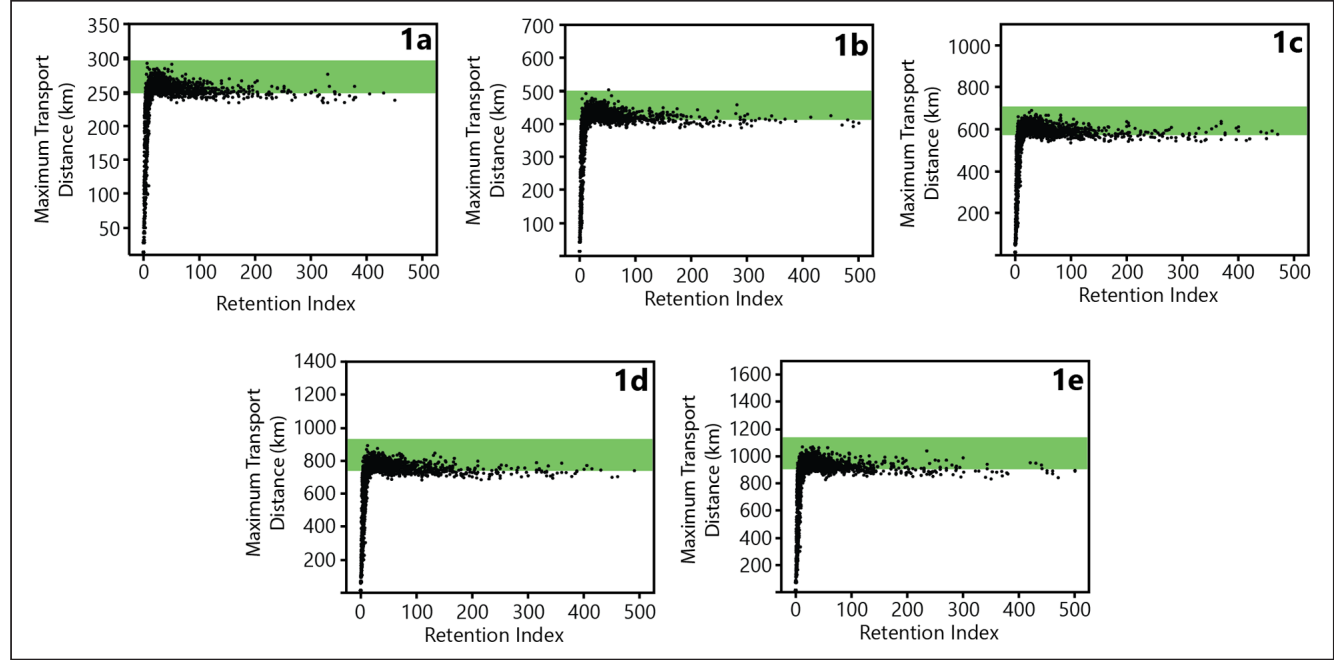

Figure 3 Experiment 1 results. Green boxes delineate the actual minimum and maximum ranges of groups. Although the scales of transport distance (as shown on the $\mathrm{Y}$ axis) vary, the pattern of the relationship between the Retention Index and transport distance is the same regardless of the scale of mobility.

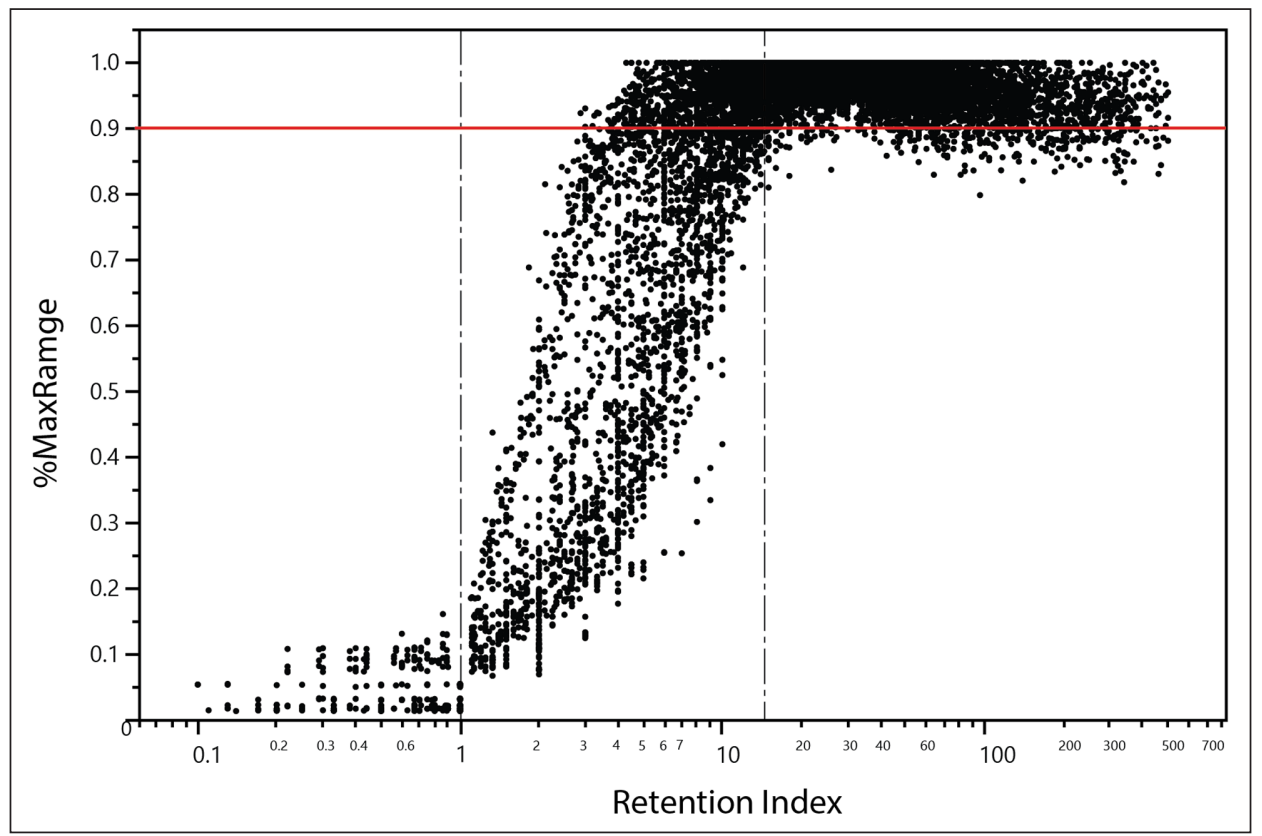

Figure 4 Results of Experiment 1 shown on a log scale. The red line marks the threshold where the maximum distance of stone tool transport distance reflects $90 \%$ of maximum group range (\%MaxRange $=0.9)$. 
$(r=-0.02)$. Note, however, that the higher correlation of inventory size with \%MaxRange can be at least partially attributed to the wider range of this variable (from 1-50 rather than from 1-10). How these different variables potentially affect tool transport patterns is explored further in Experiment 2.

\subsection{EXPERIMENT 2}

Experiment 2 explored patterning in how combinations of tool use/discard behaviors affected the ratio of $\%$ MaxRange. A total of 100,000 runs was performed, producing a mean of approximately 20 runs at each of the 5000 possible combinations of the parameters (see Table 1). Mobility settings were the same as those used in Experiment 1b.

The top chart of Figure 6 shows the same relationship between \%MaxRange and RI that was present in the data from Experiment 1. The bottom chart depicts the data in a matrix of cells representing combinations of settings for inventory size, uses per step, and use-life. Categories of the ratio of \%MaxRange are depicted with colors (also shown as a bar on the $Y$ axis of the top chart).

Inventory size has a significant effect on \%MaxRange. When inventory size is low $(<5)$ there are no combinations of use-life and uses per step that result in discard of tools at or near the maximum extent of group range: only $7 \%$ of combinations result in discard of tools at even 75\% or more of maximum range. When inventory size is high (>30), however, even technologies where tools are rapidly exhausted (i.e., tools have low use-lives and a high number of uses per step) result in discard at or near the maximum extent of group range.

Between inventory sizes of 6 and 30 there is great variability in outcomes, with cases of transport/discard of over $95 \%$ of a group's range and below $75 \%$. The proportion of high transport cases increases with inventory size but is significantly affected by use-life and uses per step. Holding inventory size constant, a simultaneous decrease in use-life and increase in uses

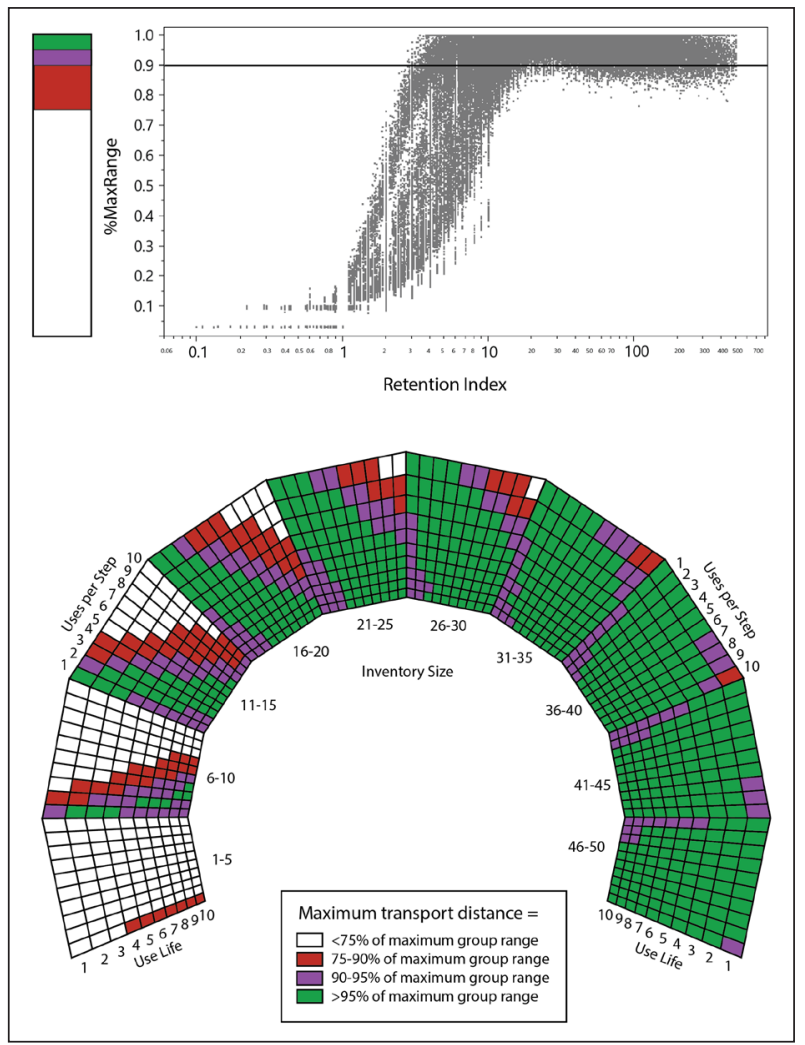

Figure 6 Experiment 2 results. Purple and green signify combinations of tool settings that produce \%MaxRange values over 0.9. The curve of the bottom portion of the figure serves simply to conserve space and is not analytically significant.

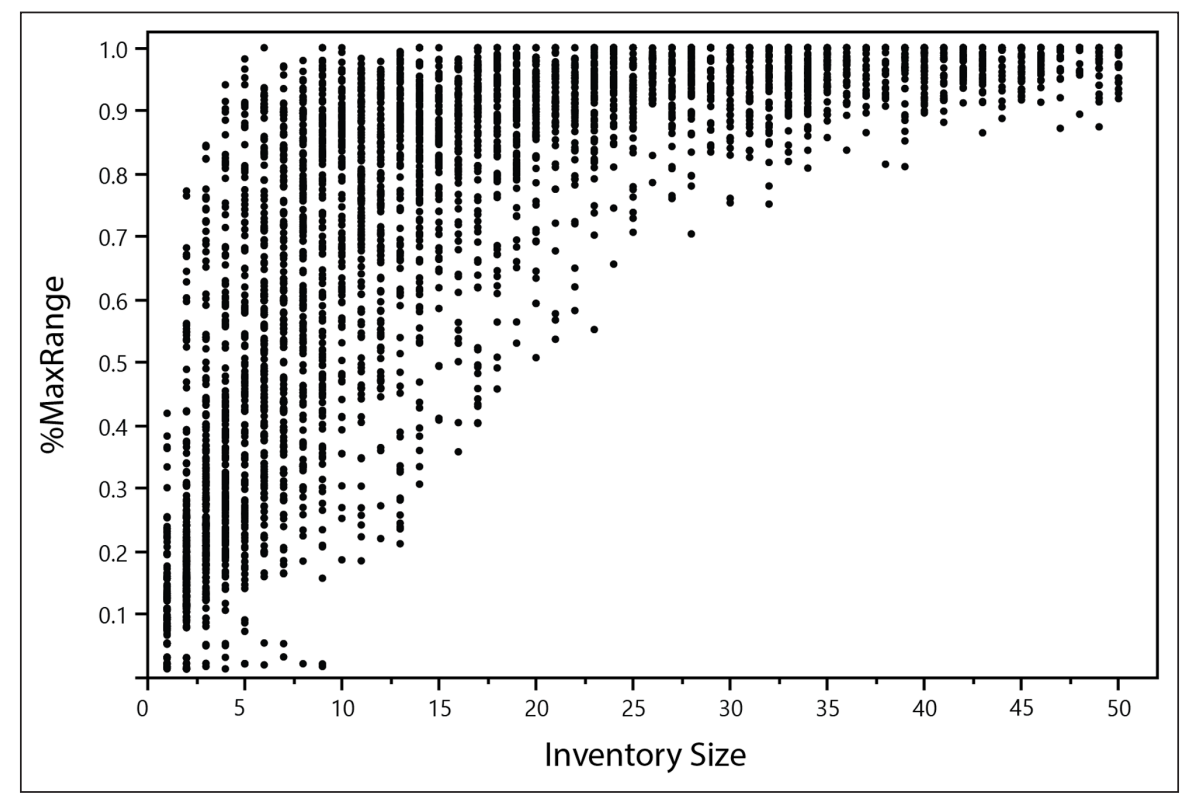

Figure 5 Relationship between inventory size and the ratio of maximum transport distance to maximum group range in cases where the Retention Index (RI) is between 1 and 14 (Experiment 1). Although there is a generally positive relationship between inventory size and RI, a wide range of values of inventory size produce \%MaxRange values over 0.9 . 
per step can reduce the \%MaxRange ratio significantly, moving it from over $95 \%$ to under $75 \%$ even with no change in underlying mobility. This range produces many of the outcomes shown in the highly variable region of the upper chart in Figure 6 (RI between 1 and 10).

Many combinations of variables produce maximum transport distances that are significantly lower than the actual maximum group ranges. Overall, about $75 \%$ of combinations had values of \%MaxRange greater than 0.9. That number drops to $15 \%$ when tool inventory size is below 10. In the universe of possible lithic strategies/ behaviors represented in the model, those with low inventory size rarely produce transport/discard patterns that accurately reflect the actual scale of group mobility.

\subsection{EXPERIMENT 3}

Experiment 3 explored the 'overproduction' of tools at the lithic source and the replacement of all used tools at the lithic source. This experiment was designed to represent behaviors often attributed to Paleoindian and Early Archaic foragers, specifically groups 'gearing up' at high quality lithic sources during scheduled visits. A total of 300,000 additional runs was performed like those in Experiment 2, holding mobility settings constant but utilizing different settings of productionFactor and replacement (see Table 1).
The results from Experiments 2, 3a, 3b, and 3c together provide data about how overproduction and replacement behaviors affect maximum transport distances. Gross differences among the four batches of experiments are apparent in the right portions of the distributions (i.e., where the RI exceeds 10) (Figure 7). In both experiments with replacement set to 'on,' \%MaxRange tends to decrease as the RI increases over 50. The cases in this downward-sloping tail are combinations of high use-life, a very low number of uses per step, and moderate to high tool inventory sizes: tools created at the raw material source do not begin to be discarded until groups are on their way back to the lithic source. In extreme cases the entire assemblage is returned to the source area prior to being discarded and replaced with a new set of tools. In contrast, the overproduction of tools at the source does not appear to affect the gross relationship between the RI and \%MaxRange.

The results from Experiment 3a, 3b, and $3 c$ can be compared to the 'null' case by subtracting them from the results of Experiment 2 . The charts on the left of Figure 8 display the log of RI on the $X$ axis and the differences in the ratio of \%MaxRange on the $Y$ axis, set to the same range in each chart. The charts on the right display the same results with a linear scale on the $\mathrm{X}$ axis.

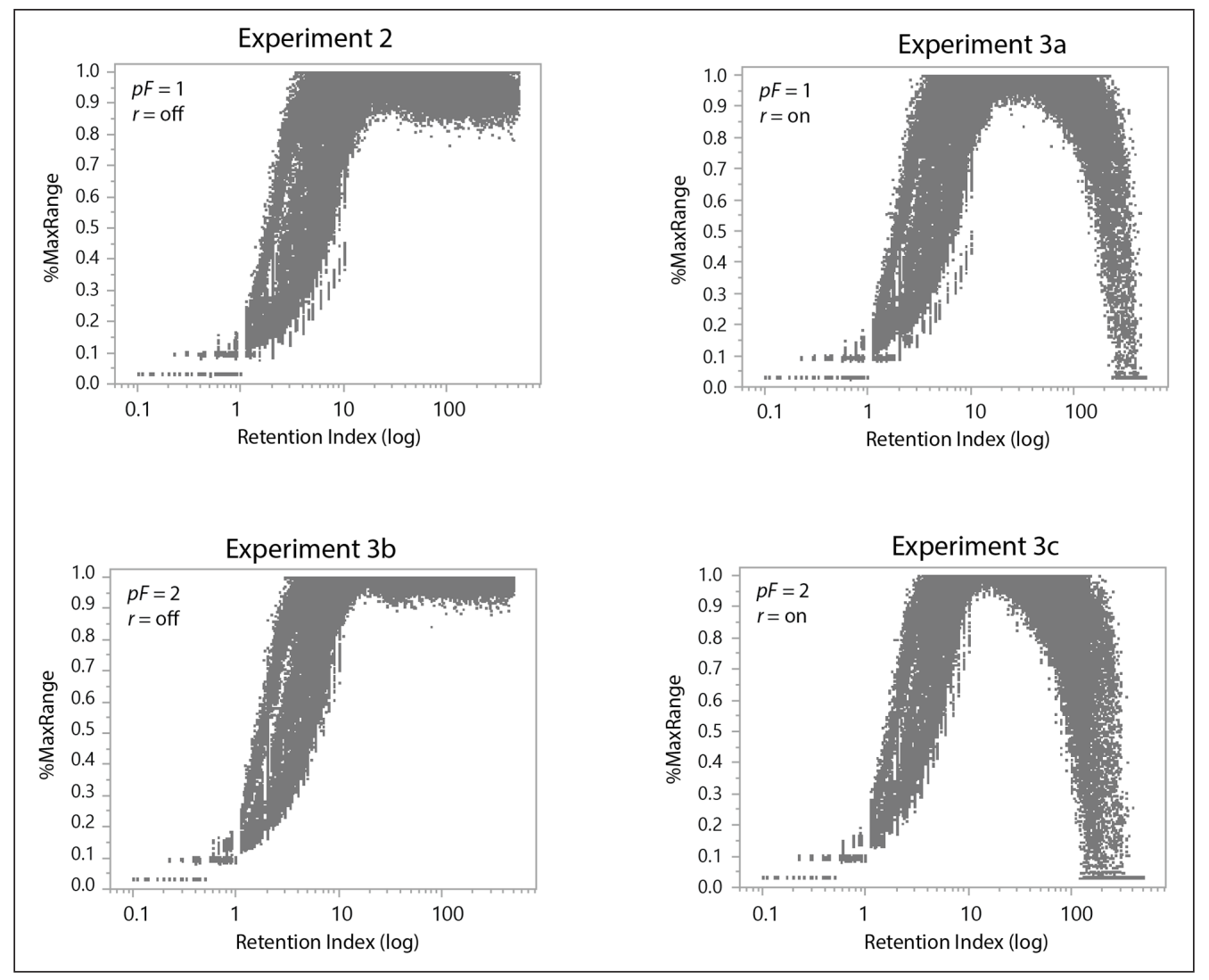

Figure 7 Experiment 3 results showing the effects of adding 'gearing up' behaviors. Experiment 2 is results with a productionFactor of 1 (no increase in production at the lithic source) and replacement set to 'off." In Experiment 3a, all tools with less than maximum utility are replaced while at the lithic source. In Experiment $3 b$, twice as many tools as required by toolInventorysize are produced while at the lithic source. In Experiment $3 c$ both of those behaviors are active. 

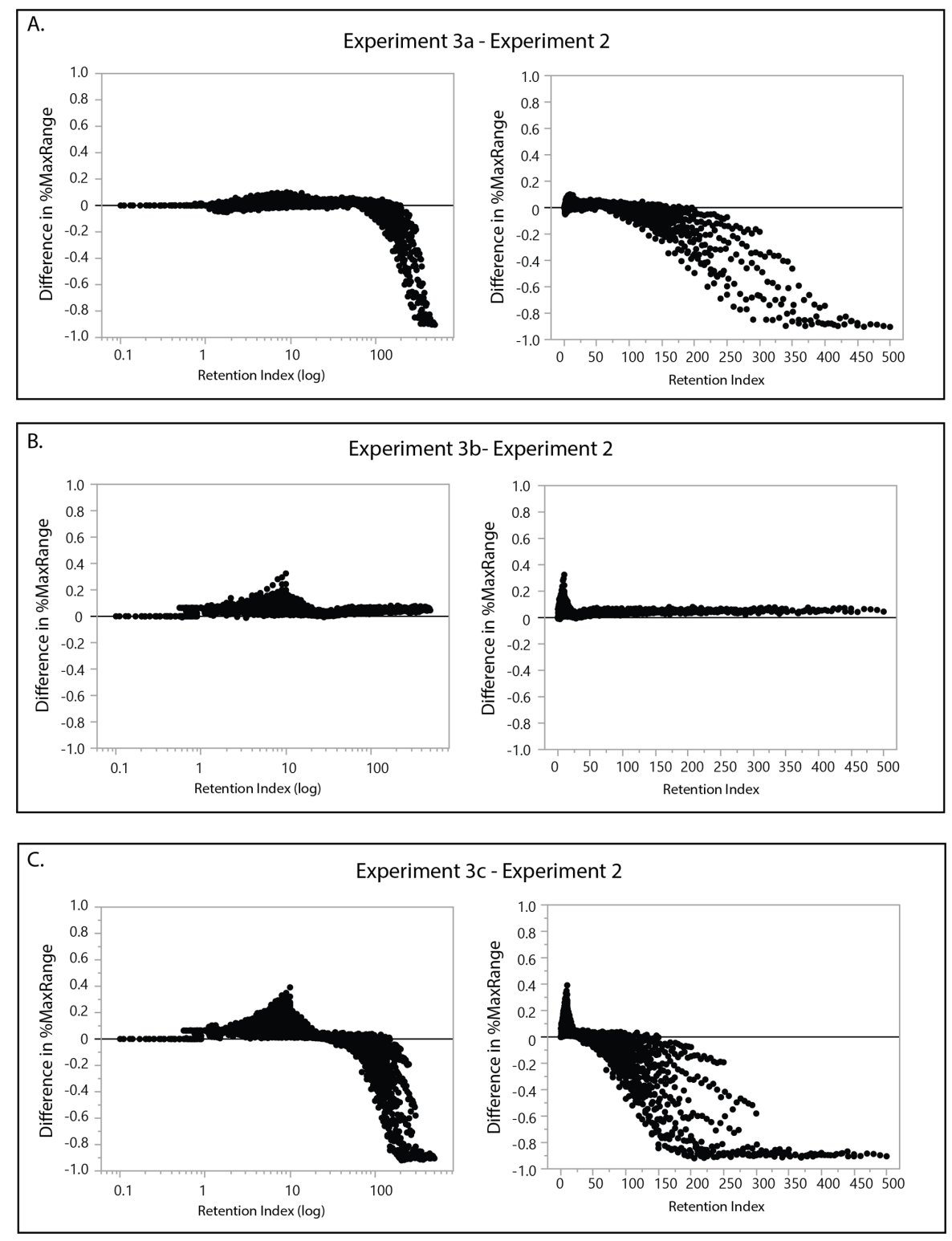

Figure 8 Differences between batches of runs in Experiment 3 and the results from Experiment 2, showing the effects of overproduction and replacement of tools at the lithic source.

The behavior of replacing tools that retain uselife would generally be expected to increase the \%MaxRange in the model runs, as groups would depart the lithic source fully stocked with new tools. This is true in the model results, as turning replacement 'on' generally results in an increase in \%MaxRange when RI is between about 1 and 50 (Figure 8A). This increase is not large, however, and never greater than $10 \%$. As RI increases over 50 the effect on \%MaxRange is negative (as discussed above). At the other extreme, some mild negative effects on the \%MaxRange ratio are produced when very low settings for inventorysize (i.e., 1 or 2 ) are combined with moderate/high settings for uselife and usesPerStep. Overall, the effect is relatively minor in either direction: turning replacement 'on' by itself changes the $\%$ MaxRange by 0.10 or less.

In Experiment 3b, replacement was off and productionFactor was set to 2. In most cases, doubling production of tools at the source has a mild positive effect on the \%MaxRange (staying below 5\%) (Figure 8B). The effect is strongest when RI is between 2 and 20. In the most extreme case, \%MaxRange increased by 0.32 .

In Experiment 3c, replacement was on and productionFactor was set to 2 . Persons near the lithic source discarded all their used tools and replenished their inventories with double the value of inventorysize. The results combine the positive effects of productionFactor in the lower range of RI and the negative effects of replacement in the higher range of RI (Figure $8 \mathrm{C}$ ).

\subsection{EXPERIMENT 4}

Experiment 4 explored differences in the fall-off patterns produced by various combinations of tool use/discard behaviors. Fall-off patterns (percentage of tools made from a specific source plotted in relation to distance from the source) are often used to estimate the scales of group mobility and/or the extent of group ranges or territories. Model data presented in terms of fall-off patterns form 
an easy basis for comparison with archaeological data presented in a similar fashion.

Six runs were selected from different parts of the distribution of outcomes of Experiment 2 (Figure 9). The settings of these runs were used to perform 20 new runs for each combination with productionFactor set to 1 and replacement 'off' $(4 a-4 f)$ and 20 new runs for each combination with productionFactor set to 2 and replacement 'on' (4g-4l) (see Table 1). As in Experiment 3, these settings represent a range of 'gearing up' behaviors.

Results were averaged to produce a single mean falloff curve for each batch of runs (Figure 10). The $Y$ axis displays the percentage of discarded tools made from the lithic source and the $X$ axis displays the distance from the lithic source in a series of $20 \mathrm{~km}$ 'bins.' Each chart shows the mean of the runs with productionFactor set to 1 and replacement 'off' (solid line) and productionFactor set to 2 and replacement 'on' (dashed line).

Because mobility parameters were held constant, we know that all of the variability in Figure 10 was caused by variation in tool production, use, and discard behaviors. It is important to remember that the fall-off curves are constructed from tools discarded on the model landscape during movements both away from and toward the lithic source.

\subsubsection{Experiments $4 \mathrm{a}$ and $4 \mathrm{~g}$}

These runs combined a low inventory size with a moderate use-life and a high number of uses per step (Figure 10A). Because more uses are 'spent' each step then are present in the tool kit, tools are exhausted and replaced rapidly. Because choices about which tools to use are randomized, some tools persist in the tool kit for multiple steps. The high turnover rate means that tools made at the lithic source are quickly exhausted and discarded as groups move away from the source. A few tools survive for multiple steps, producing a weak tail extending out to about $12-16 \%$ of the actual group range. Replacing all used tools with double the tool inventory at the source (Experiment $4 \mathrm{~g}$ ) changes the falloff curve only slightly. The high rate of exhaustion quickly expends the extra utility acquired at the source and the sourced lithic tools are discarded within a few steps.

\subsubsection{Experiments $4 \mathrm{~b}$ and $4 \mathrm{~h}$}

These runs combined a low inventory size with moderate-high use-life and a high number of uses per step (Figure 10B). This combination provides a maximum of 21 potential uses in a toolkit, nine of which (43\%) are spent each step. This increased potential utility of the tool kit relative to Experiment 4 a results in a slightly longer tail: sourced lithic tools are discarded up to $17-21 \%$ of maximum group range. When there is no replacement or overproduction at the source, about $68 \%$ of the tools in the source area are made from the lithic source. The tool kits of groups returning to the source area contain only non-source tools which are used, discarded, and replaced while groups are in the source area.

The Experiment $4 \mathrm{~h}$ fall-off curve (where replacement is 'on' and tool production is doubled at the lithic source) differs markedly from the $4 b$ curve in three ways: (1) it begins higher, with about $90 \%$ of the tools at the source area being manufactured from source materials; (2) a sharp drop is followed by a significant increase in the percentage of sourced tools at 40-60 km from the source; and (3) the tail of sourced tools extends farther (25-31\% of maximum group range). Replacement and overproduction of tools results in groups leaving the

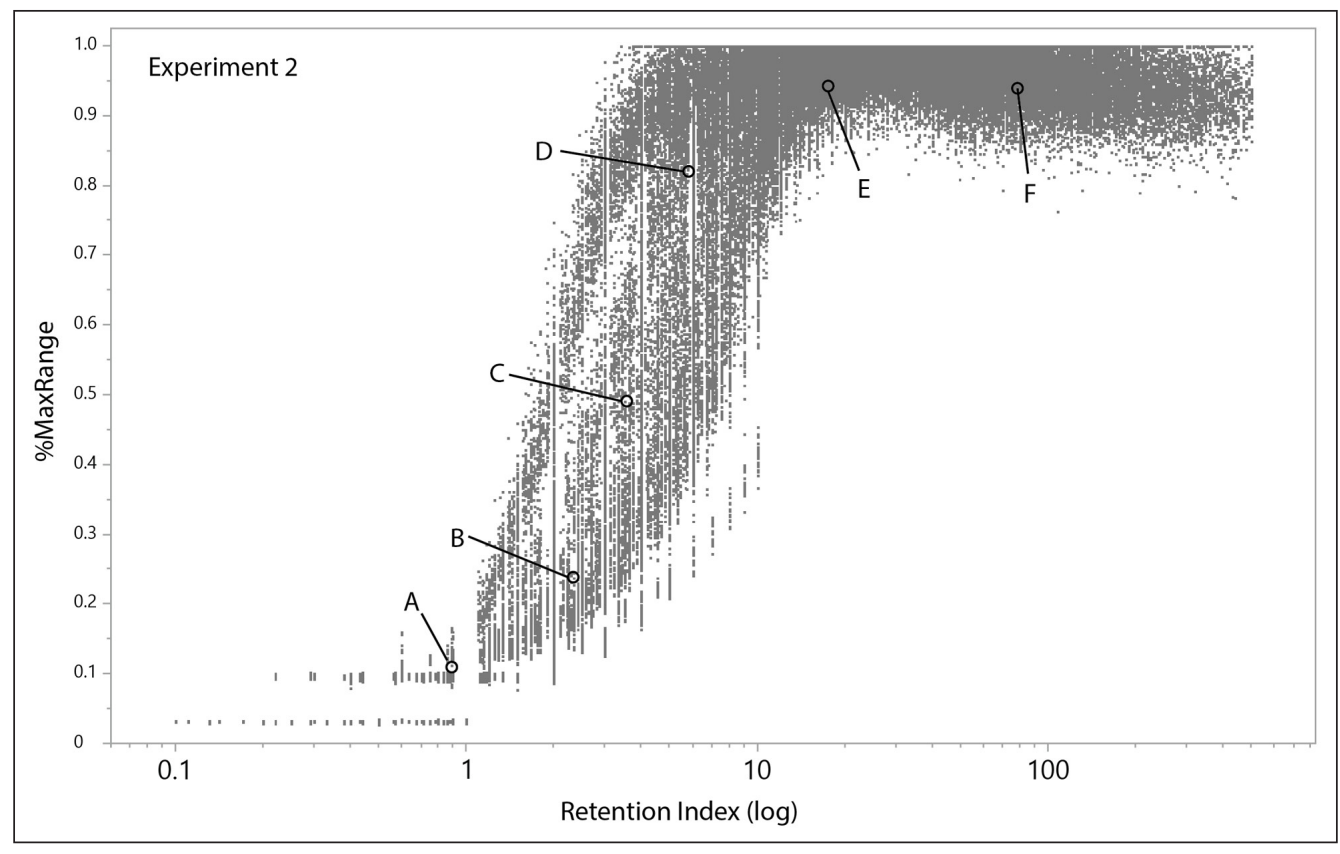

Figure 9 Experiment 2 results showing locations of example runs chosen for additional investigation in Experiment 4. 


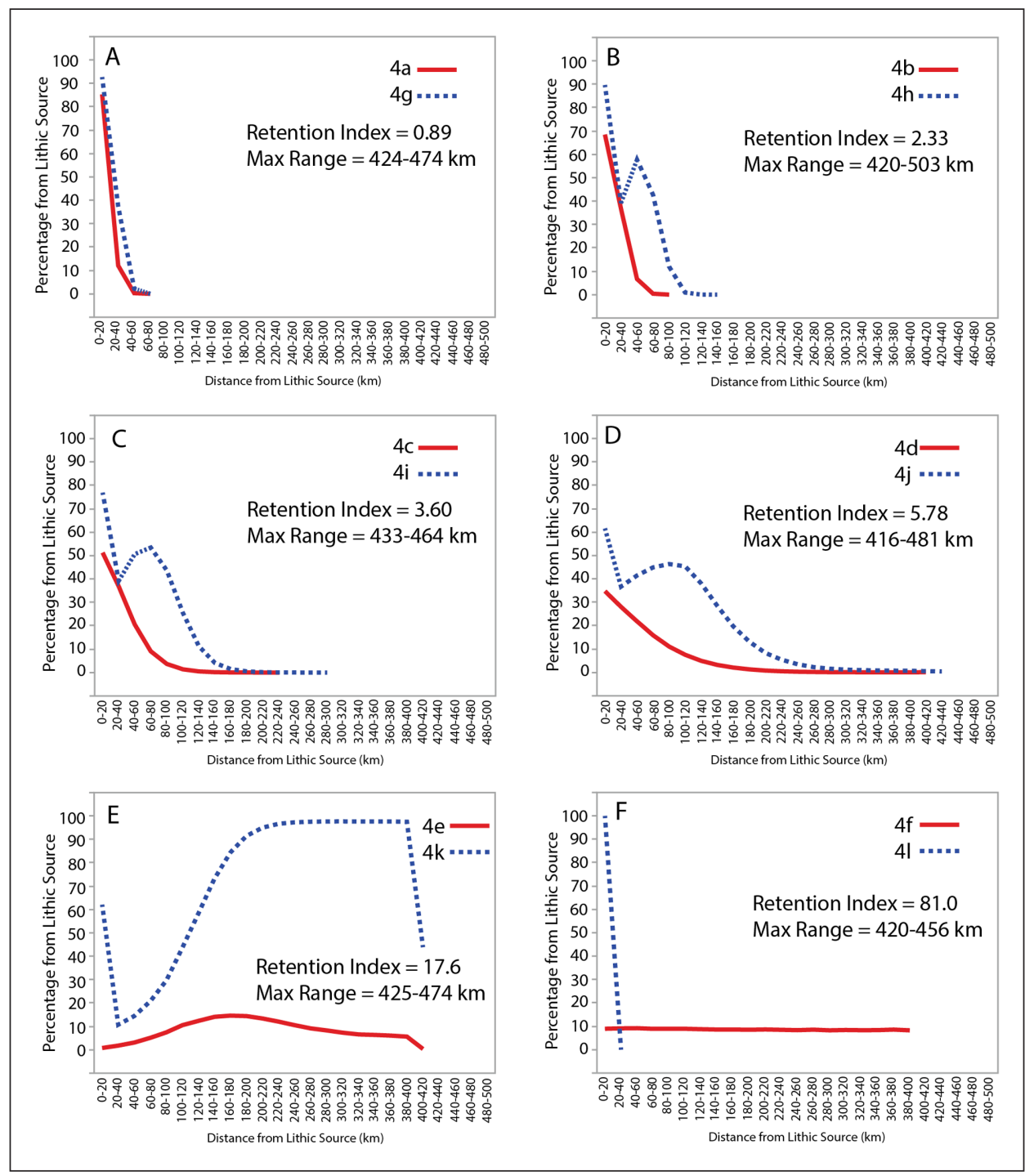

Figure 10 Fall-off patterns produced by runs in Experiment 4. Solid red lines show the fall-off patterns of runs with no 'gearing up' behaviors at the lithic source (no overproduction of tools and no replacement of tools that retain utility); dashed blue lines show results from runs with identical settings except for doubled production of tools at the lithic source and replacement at the lithic source of all tools with less than full utility remaining. The difference between the two lines is caused by the 'gearing up' behaviors.

source area with toolkits containing 42 potential uses, twice the number as in Experiment 4b. Because only $21 \%$ of the utility of this 'overproduced' tool kit is used on the first step away from the source area, relatively few tools are exhausted and discarded. As movement away from the source area continues, however, more tools are exhausted and discarded. This results in the 'bump' at $40-60 \mathrm{~km}$ from the source area. Once the tool kit is depleted to inventorySize, exhausted tools are replaced by tools made with unsourced material. This results in the remainder of the fall-off curve looking similar to that of Experiment 4b. Groups moving back toward the lithic source discard tools made from non-source material, reducing the overall percentages of sourced tools.

\subsubsection{Experiments $4 \mathrm{c}$ and $4 \mathrm{i}$}

These runs combined a moderate inventory size, low use-life, and a high number of uses per step (Figure 10C).
While the overall patterns of the fall-off curves are similar to Experiments $4 \mathrm{~b}$ and $4 \mathrm{~h}$, the increased utility of the tool kit produces longer tails and lower percentages of tools made from source material in the source area. Tools made from the lithic source were moved distances equal to $43-59 \%$ of the groups' maximum range in Experiment 4c, $57-72 \%$ in Experiment $4 \mathrm{i}$.

\subsubsection{Experiments $4 d$ and $4 j$}

These runs combined a high inventory size, low uselife, and a high number of uses per step (Figure 10D). The overall patterns of the fall-off curves are similar to Experiments 4b, 4c, 4h, and 4i, continuing the trend of longer tails and lower percentages of tools made from the source material in the source area. This is, again, a result of the increased potential utility of the tool kit. Tools made from the lithic source were moved $80-96 \%$ of the groups' maximum range in Experiment 4d, 91-100\% 
in Experiment 4j. Thus the conditions in many of these runs produced outcomes where stone tool transport was a good reflection of maximum group range.

\subsubsection{Experiments $4 \mathrm{e}$ and $4 \mathrm{k}$}

These runs combined a moderate inventory size, high uselife, and moderate number of uses per step (Figure 10E). The patterns produced by this combination are very different from the previous experiments. In Experiment 4e (with no replacement or overproduction at the lithic source) the fall-off 'curve' is more like a gentle hill with its apex nearly $200 \mathrm{~km}$ from the source area. New tools made at the lithic source are exhausted after eight uses. When only five uses per step are randomly distributed among 11 tools, it is unlikely that any tools will be exhausted immediately after manufacture. Thus tools made at the lithic source do not begin to be exhausted until well into the groups' travels away from the lithic source area. Some sourced tools are still present in the tool kit for the return trip to the lithic source area, and it is probable that some tools make it all the way back to the source area. The flatness of this fall-off curve is a product of the low turnover of tools in the tool inventory produced by the combination of moderate inventory size and high use-life.

Experiment $4 \mathrm{k}$ produced a very different pattern. Given replacement and overproduction, tool kits being carried away from the source area contained 116 potential uses, resulting in some tools being carried the full year before being discarded and replaced at the source area. At $200-400 \mathrm{~km}$ from the source area, about $97 \%$ of the discarded tools were manufactured from the lithic source. The proportion of sourced tools being discarded decreases in the final stages of the journey back to the lithic source, presumably as replacement tools made from non-sourced materials are finally represented in sufficient number in the tool kit to be exhausted and discarded.

\subsubsection{Experiments $4 \mathrm{f}$ and $4 \mathrm{l}$}

These runs combined a large inventory size, high uselife, and low number of uses per step (Figure 10F), representing a tool kit that would take over a year to completely exhaust even it was not being replenished. This results in a constant $8-10 \%$ of sourced tools in the discarded assemblages and no recognizable 'fall-off' from the lithic source.

Adding overproduction and replacement (Experiment 4l) produces a pattern where all tools discarded at the lithic source are made from sourced material and no tools are discarded outside the source area. This is because tools are never completely exhausted and thus are not discarded unless they are being replaced at the source. Groups in this scenario effectively move across the landscape without leaving any trace in the form of discarded tools.

\section{DISCUSSION}

The four batches of computational experiments described above demonstrate that

1) The parameters that affect the use/discard of stone tools have significant effects on the maximum distances to which stone tools are transported;

2) The relationship between the RI (a metric of the proportional rate of discard) and maximum tool transport distance is nonlinear, and all three discard/ use parameters contribute to the accuracy with which maximum tool transport distance reflects maximum group range;

3) In a large number of cases, maximum transport distance significantly underestimates maximum group range;

4) The replacement and overproduction behaviors in the model generally increase the accuracy with which maximum tool transport distances reflect maximum group range, but the effects are complex and do not apply equally to all circumstances.

Although these observations apply strictly only to the world of the model, they provide a useful framework for thinking about the degree to which stone tool transport distances reflect group range in archaeological cases. Model results are consistent with the idea that strategies that cycle through tools quickly will significantly underestimate mobility based on raw material transport. Thus, in the absence of exchange as a contributing mechanism, we should regard fall-off patterns as reflecting the minimum scale of group mobility (averaged over time) rather than the maximum, assuming mobility patterns stay constant (i.e., range does not shift spatially from one period of time to the next). Strategies that employ high numbers of high use-life tools will also tend to significantly underestimate mobility in the context of a 'tethered' system, as these tools may be discarded on the return trip rather than at a group's maximum distance from the source. Systems with a low rate of discard will also discard fewer tools over time, potentially creating a drop in point numbers that could be mistaken for a demographic decrease.

The modeling work included many scenarios which are almost certainly outside the bounds of the behaviors of actual mobile hunter-gatherer societies, as least with respect to the use and transport of stone points. At one extreme are 'purely expedient' strategies where tools are made, used once, and then discarded. At the other extreme are cases where large inventories of long-lasting tools are moved around the landscape, used infrequently, and only rarely exhausted and discarded. Archaeological data clearly demonstrate that such 'extreme' systems were not in place among the early hunting-gathering societies of eastern North America: repair, rejuvenation, 
and discard were integral features of their technological systems. The model results at these extremes are helpful, however, in that they are examples of what not to expect in archaeological cases. It is interesting that the two opposite extremes represented by the fall-off curves of Experiments $4 \mathrm{~g}$ and $4 \mathrm{l}$ (see Figure 10) produce nearly identical results but for very different reasons.

Within the 'middle zone' of the model explorations are many possible combinations of tool manufacture, use, and discard behaviors that produce fall-off patterns qualitatively similar to those documented in archaeological cases. In some of these cases, transport scale accurately reflects group range. In others, transport distances significantly underestimate how far groups actually travelled. Underestimates occur when the utility of tools manufactured at the source is exhausted before the maximum range is reached. Technological changes that affect the amount of utility in a tool inventory clearly have the potential to alter the accuracy with which the scale of lithic transport reflects the scale of group mobility. Holding other variables equal, increasing the number of tools in the inventory will increase the utility, as will strategies for prolonging use-life (such as using bevel resharpening to maintain blade edges) and changes to design that make tools more resistant to breakage. These kinds of changes would appear archaeologically as an increase in transport distance in the absence of any change in mobility.

The model results can be used to briefly frame some issues that arise in interpretation of the 'high-lowerhigher' pattern of changes in stone tool transport distance that occurred during the 4000 years of the Paleoindian and Early Archaic periods in the Eastern Woodlands. The most dramatic changes to transport distances and aspects of point design, use, and resharpening occurred between the Early to Late Paleoindian periods (less is known about the intervening Middle Paleoindian period). In terms of transport distances, the Late Paleoindian period saw a significant decrease in the scales of raw material transport relative to the Early Paleoindian period (see Anderson et al. 1990; Jennings 2008b; Koldehoff and Loebel 2009; Smallwood et al. 2015; White 2014). This was accompanied by a suite of changes related to point maintenance, rejuvenation, and recycling. Dalton points, perhaps the best documented Late Paleoindian artifacts, were often carefully maintained through alternate edge beveling (a strategy used to preserve blade length through multiple resharpenings), recycled into other tool forms, and discarded with little remaining utility (see Craib 2016; Goodyear 1974; Shott and Ballenger 2007; Tune 2016; Walthall and Koldehoff 1999). This suggests that Dalton points were often used primarily as hand tools (saws, knives, drills, etc.) rather than primarily as projectile tips as suggested for Early Paleoindian points like Clovis (see Tune 2016). If so, Dalton points probably had longer use-lives than earlier fluted points, governed more by attrition (resharpening) than by chance breakage (see Shott and Sillitoe 2004:352).

The modeling experiments discussed above demonstrate that, other things being equal, we should expect increases in toolkit longevity to be associated with increases in maximum transport distance. The opposite seems to be true in this case, where an increase in use-life was accompanied by a decrease in the scales of transport. Thus it is unlikely that a change in use-life alone explains the change in raw material transport patterns: all other things were not equal.

It is possible that some other change in toolkit utility occurred along with an increase in use life. If multi-functional Dalton points were used frequently in a variety of fabrication, processing, and maintenance tasks in addition to functioning as projectile tips, they may have been used more frequently than Clovis points (in terms of the model, the 'uses per step' was greater for Dalton points) and thus exhausted at an equal or higher rate even though their use-life was greater. This is a reasonable proposition, and one which would be consistent with both a reduction in maximum transport distance and an increase in the number of discarded Dalton points relative to Clovis (see Koldehoff and Loebel 2009). A drop in tool inventory size could also have contributed to decreased transport distances. Unfortunately, as discussed above, we have few pieces of positive data upon which to base reconstructions of tool inventory size (see Deller et al. 2009).

Importantly, the idea that the scales of mobility of Late Paleoindian groups in the Eastern Woodlands decreased relative to that of Early Paleoindian groups is supported by negative evidence: some portions of the landscape that were occupied by Early Paleoindian groups simply appear to have been unoccupied during the Late Paleoindian period, suggesting that populations contracted into some areas while abandoning others (see White 2012). In the Middle Mississippi Valley, for example, there is a paucity of evidence for Dalton settlement farther out on the Till Plain than the $50 \mathrm{~km}$ suggested by raw material distributions (Koldehoff 2013; Walthall and Koldehoff 1999:45). In other words, it is not just that raw material distributions have a geographic end, but also that evidence for intensive occupation is absent outside of those raw material distribution zones. The contraction of populations would be consistent with both a reduction in the scales of mobility and an increased density of sites in some areas and the absence of sites in others. Thus it seems plausible that Dalton tool maintenance behaviors were employed to offset increased use of the tools as multi-functional implements within a mobility strategy where groups moved significantly shorter distances on average than in earlier Paleoindian societies. If so, the fall-off patterns for Late Paleoindian points may provide good estimates of the scales of group mobility. 
A close examination of fall-off patterns and the characteristics of lithic assemblages during the Early and Late Paleoindian periods may help sharpen explanations of contrasts in transport distance. It is notable that simple 'neutral' models of lithic resource use produce fall-off patterns that are at least qualitatively similar to the patterns we see archaeologically and in the experiments described here (see Brantingham 2003; Pop 2016). That such patterns are produced by random movements that simply intersect raw material sources by chance suggests caution is in order when interpreting the geographic distribution of raw materials as delineating a "range" or "territory." Further model-based analysis may help us develop a finer understanding of what we might and might not be able to learn from the nuances of fall-off patterns. The modeling work discussed by Barton and Riel-Salvatore (2014) shows how aspects of lithic assemblage composition link to mobility strategies, highlighting an additional line of evidence that could be used to understand changes in the overall scale and structure of mobility among Late Pleistocene and Early Holocene foragers in the Eastern Woodlands.

While the model results alone cannot pinpoint the cause of changes in particular cases, they can be used to build general expectations about the direction and magnitude of changes in transport patterns linked to changes in use-life, tool inventory size, and frequency of use. When multiple variables are in play changes in the scales of group mobility cannot be assessed simply by comparing transport distances. The potential for equifinality issues is apparent both within the world of the model (many different combinations of tool use/ discard behaviors can produce similar transport patterns) and within archaeological cases that are situated within larger contexts of changing natural, social, and technological environments. Other mechanisms of transport - logistical procurement, personal mobility, and/or exchange - that potentially contribute to stone tool transport among mobile foragers in this case (e.g., Cantin 2000; Jennings 2008a; Smallwood et al. 2015; Speth et al. 2013; Speth 2018; White 2014) and others are not represented in the model as it currently stands. Additional work will be required to systematically address these issues.

\section{CONCLUSION}

The model-based analysis shows that there are patterned relationships between tool use/discard behaviors and tool transport distances. The simple idea that tool attrition is linked to transport distance is not new (see Buchanan 2006; Jennings 2008a; Nolan and Fishel 2009:430). What the model-based analysis contributes is (1) the identification of non-linearities in those relationships and (2) an understanding of the nature and magnitude of those nonlinearities. Relatively small differences in tool production, use, and discard behaviors can 'map up' to significant differences in the distances that tools are transported and the fall-off patterns that we can observe archaeologically.

The equifinality issues demonstrated by the model highlight the value of using multiple lines of evidence to interpret changes in group mobility in archaeological cases. Environmental reconstructions, subsistence data, and direct evidence gathered from methods like usewear analysis and protein residue analysis can help build context for studies of how tool use/discard behaviors are linked to group mobility. Negative evidence - the absence of sites from large regions, for example - may be useful in some cases for evaluating whether decreases in transport distance are connected to demographic abandonment of regions or changes in technological behaviors.

The model results provide a useful starting point for understanding general relationships but are not a substitute for more detailed modeling of individual cases. The simple model used here represents a specific structure of mobility and lithic procurement, one which may not match many aspects of archaeological cases. Construction of different models will be required to generate data directly comparable to specific archaeological cases. Such models could incorporate different mechanisms of raw material acquisition, different mechanisms of transport (e.g., exchange, intergroup movements by individuals), different patterns of movement and aggregation, and different seasonal behaviors. They could also include a more realistic spatial world (i.e., with the locations of actual raw material sources represented to scale) and record information about the distribution of the 'sites' and assemblages that are created. These kinds of ambitious modeling efforts would require a significantly greater investment in development than was required for the generalized model used here.

\section{ACKNOWLEDGEMENTS}

I thank the anonymous reviewers for their comments and suggestions which served to strengthen this paper. I began this work while employed at the University of South Carolina and completed it at the Illinois State Archaeological Survey.

\section{COMPETING INTERESTS}

The author has no competing interests to declare. 


\section{AUTHOR AFFILIATION}

Andrew White (D) orcid.org/0000-0002-4419-3903

University of Illinois, US

\section{REFERENCES}

Anderson, DG and Hanson, GT. 1988. Early Archaic settlement in the southeastern United States: A case study from the Savannah River Valley. American Antiquity, 53(2): 262-286. DOI: https://doi.org/10.2307/281019

Anderson, DG, Ledbetter, RJ and O'Steen, LD. 1990. Paleoindian period archaeology of Georgia. Georgia Archaeological Research Design Paper 6. University of Georgia Laboratory of Archaeology Series Report 28. Athens, GA: University of Georgia Press.

Arrizabalaga, A, Calvo, A, Elorrieta, I,Tapia, J and Tarriño, A 2014. Where to and what for? Mobility patterns and the management of lithic resources by Gravettian hunter-gatherers in the Western Pyrenees. Journal of Anthropological Research, 70(2): 233-61. DOI: https://doi. org/10.3998/jar.0521004.0070.204

Bamforth, DB. 2009. Projectile points, people, and Plains Paleoindian perambulations. Journal of Anthropological Archaeology, 28: 142-157. DOI: https://doi.org/10.1016/j. jaa.2009.01.002

Barton, CM and Riel-Salvatore, J. 2014. The formation of lithic assemblages. Journal of Archaeological Science, 46: 334352. DOI: https://doi.org/10.1016/j.jas.2014.03.031

Binford, LR. 1979. Organization and formation processes: Looking at curated technologies. Journal of Anthropological Research, 35(3): 255-273. DOI: https://doi.org/10.1086/ jar.35.3.3629902

Binford, LR. 2001. Constructing frames of reference: An analytical method for archaeological theory building using hunter-gatherer and environmental data sets. Berkely: University of California Press.

Birdsell, JB. 1968. Some predictions for the Pleistocene based on equilibrium systems among recent huntergatherers. In: Lee, RB and DeVore, I (eds.), Man the Hunter, 229-240. Chicago: Aldine. DOI: https://doi. org/10.4324/9780203786567-29

Brantingham, PJ. 2003. A neutral model of stone raw material procurement. American Antiquity, 68(3): 487-509. DOI: https://doi.org/10.2307/3557105

Brose, DS. 1994. Archaeological investigations at the Paleo Crossing site, a Paleoindian occupation in Medina County, Ohio. In: Dancey, WS (ed.), The first discovery of America, 61-76. Columbus, Ohio: The Ohio Archaeological Council.

Buchanan, B. 2006. An analysis of Folsom projectile point resharpening using quantitative comparisons of form and allometry. Journal of Archaeological Science, 33: 185-199. DOI: https://doi.org/10.1016/j.jas.2005.07.008

Burke, A. 2006. Paleoindian ranges in northeastern North America based on lithic raw materials sourcing. In: Bressy, CC, et al. (eds.), Notions de territoire et de mobilité:
Exemples de l'Europe et des premières nations en Amérique du Nord avant le contact Européen, 77-89. Liège: Études et Recherches Archéologiques de l'Université de Liège.

Cantin, ME. 2000. Comparative analysis of Thebes and Kirk lithic technology and home range implications in southwestern Indiana. Unpublished thesis (MA), Indiana State University.

Carr, DH. 2005. The organization of Late Paleoindian lithic procurement strategies in western Wisconsin. Midcontinental Journal of Archaeology, 30(1): 3-35. DOI: https://doi.org/10.1179/mca.2005.001

Carr, DH. 2011. Paleoindian economic organization in the lower Great Lakes region: Evaluating the role of caribou as a critical resource. Unpublished dissertation (PhD), Michigan State University.

Cheshier, J and Kelly, R. 2006. Projectile point shape and durability: The effect of thickness:length. American Antiquity, 71(2): 353-363. DOI: https://doi. org/10.2307/40035908

Coco, E, Holdaway, S and Iovita, R. 2020. The effects of secondary recycling on the technological character of lithic assemblages. Journal of Paleolithic Archaeology, 3: 453474. DOI: https://doi.org/10.1007/s41982-020-00055-4

Conkey, MW. 1980. The identification of prehistoric huntergatherer aggregation sites: The case of Altamira. Current Anthropology, 21: 609-630. DOI: https://doi. org/10.1086/202540

Craib, A. 2016. Dalton mobility in the Tennessee River Valley: An assessment of raw material use and tool curation. Unpublished thesis (MA), University of Tennessee.

Custer, JF, Cavallo, JA and Stewart, RM. 1983. Lithic procurement and Paleo-Indian settlement patterns on the Middle Atlantic Coastal Plain. North American Archaeologist, 4(4): 263-276. DOI: https://doi.org/10.2190/192L-TCCHEMJL-4D9G

Daniel, IR Jr. 2001. Stone raw material availability and Early Archaic settlement in the southeastern United States. American Antiquity, 66(2): 237-265. DOI: https://doi. org/10.2307/2694607

Davies, B, Holdaway, SJ and Fanning, PC. 2018. Modeling relationships between space, movement, and lithic geometric attributes. American Antiquity, 83(3): 444-461. DOI: https://doi.org/10.1017/aaq.2018.23

Deller, DB, Ellis, CJ and Keron, JR. 2009. Understanding cache variability: A deliberately burned Early Paleoindian tool assemblage from the Crowfield site, southwestern Ontario, Canada. American Antiquity, 74(2): 371-397. DOI: https:// doi.org/10.1017/S0002731600048642

Donadei, JP. 2019. Local and nonlocal rocks: Technological strategies and raw material management. Huntergatherer mobility for mid-Holocene groups of Eastern Tandilia Range (Argentina). Journal of Archaeological Science: Reports, 24: 264-275. DOI: https://doi. org/10.1016/j.jasrep.2019.01.011

Ellis, CJ. 2011. Measuring Paleoindian range mobility and landuse in the Great Lakes/Northeast. Journal of Anthropological 
Archaeology, 30: 385-401. DOI: https://doi.org/10.1016/j. jaa.2011.05.001

Gardner, WM. 1974. The Flint Run Complex: Pattern and process during the Paleo-Indian to Early Archaic. In: Gardner, WM (ed.), The Flint Run Paleo-Indian Complex: A Preliminary Report 1971-73 Seasons, 5-47. Occasional Publication Number 1, Archaeology Laboratory, Department of Anthropology. Washington, DC: The Catholic University of America.

Gardner, WM. 1983. Stop me if you've heard this one before: the Flint Run Paleoindian Complex revisited. Archaeology of Eastern North America, 11: 49-64. https://www.jstor.org/ stable/40914222

Goodyear, AC. 1974. The Brand site: A techno-functional study of a Dalton site in northeast Arkansas. Arkansas Archaeological Survey Research Series No. 7. Fayetteville, Arkansas: Arkansas Archaeological Survey.

Goodyear, AC. 1979. Hypothesis for the use of cryptocrystalline raw materials among Paleoindian groups of North America. Research Manuscript Series 1, South Carolina Institute of Archeology and Anthropology. Columbia, South Carolina: University of South Carolina. DOI: https://doi. org/10.4324/9780429049743-1

Goodyear, AC, Radisch, W, Wetmore, R and Tippitt, VA. 2004. A Kirk Corner-Notched point cache from the Nipper Creek site (38RD18), South Carolina. Current Research in the Pleistocene, 21: 42-44.

Gravel-Miguel, C, Murray, JK, Schoville, BJ, Wren, CD and Marean, CW. 2021. Exploring variability in lithic armature discard in the archaeological record. Journal of Human Evolution, 155: 102981. DOI: https://doi.org/10.1016/j. jhevol.2021.102981

Jennings, TA. 2008a. San Patrice technology and mobility across the Plains-Woodland border. Oklahoma Anthropological Society Memoir 12. R. E. Bell Monographs in Anthropology No. 5. Norman, Oklahoma: Sam Noble Oklahoma Museum of Natural History, University of Oklahoma.

Jennings, TA. 2008b. San Patrice: An example of Late Paleoindian adaptive versatility in south-central North America. American Antiquity, 73(3): 539-559. DOI: https:// doi.org/10.1017/S0002731600046862

Kelly, RL. 1995. The foraging spectrum. Washington, D.C.: Smithsonian Institution Press.

Koldehoff, B. 2013. Paleoindian and Archaic settlement and lithic procurement in the Illinois uplands. Technical Reports No. 148. Champaign, Illinois: Illinois State Archaeological Survey, Prairie Research Institute, University of Illinois at Urbana-Champaign.

Koldehoff, B and Loebel, TJ. 2009. Clovis and Dalton: Unbounded and bounded systems in the Midcontinent of North America. In: Adams, B and Blades, BS (eds.), Lithic materials and Paleolithic societies, 270-287. West Sussex, UK: Wiley-Blackwell. DOI: https://doi. org/10.1002/9781444311976.ch20

Kusimba, SB and Kusimba, CM. 2003. Comparing prehistoric and historic hunter-gatherer mobility in southern Kenya.
In: Kusimba, CM and Kusimba, SB (eds.), East Africa archaeology: Foragers, potters, smiths, and traders, 1-16. Philadelphia, Pennsylvania: University of Pennsylvania Press. DOI: https://doi.org/10.9783/9781934536261.1

Loebel, TJ. 2005. The organization of Early Paleoindian economies in the western Great Lakes. Unpublished dissertation (PhD), University of Illinois at Chicago.

Meltzer, DJ. 1984. On stone procurement and settlement mobility in eastern fluted point groups. North American Archaeologist, 6(1): 1-24. DOI: https://doi.org/10.2190/TOJLP9E8-X45J-QBDX

Morse, DF. 1977. Sloan: A Paleoindian Dalton cemetery in Arkansas. Washington, D.C.: Smithsonian Institution Press.

Mullet, AN. 2009. Paleoindian mobility ranges predicted by the distribution of projectile points made of Upper Mercer and Flint Ridge flint. Unpublished thesis (MA), Kent State University.

Nolan, DJ and Fishel, RL. 2009. Archaic cultural variation and lifeways in west-central Illinois. In: Emerson, TE, et al (eds.), Archaic Societies: Diversity and Complexity Across the Midcontinent, 401-490. Albany, New York: State University of New York Press.

Pop, CM. 2016. Simulating lithic raw material variability in archaeological contexts: A re-evaluation and revision of Brantingham's neutral model. Journal of Archaeological Method and Theory, 23(4): 1127-1161. DOI: https://doi. org/10.1007/s10816-015-9262-y

Preston, PR. 2009. Cache and carry: Lithic technology and Mesolithic mobility. Internet Archaeology. DOI: https://doi. org/10.11141/ia.26.25

Preston, PR and Kador, T. 2018. Approaches to interpreting Mesolithic mobility and settlement in Britain and Ireland. Journal of World Prehistory, 31: 321-345. DOI: https://doi. org/10.1007/s10963-018-9118-y

Sassaman, KE, Hanson, GT and Charles, T. 1988. Raw material procurement and the reduction of hunter-gatherer range in the Savannah River Valley. Southeastern Archaeology, 7(2): 79-94. https://www.jstor.org/stable/40712876

Schiffer, MB. 1987. Formation processes of the archaeological record. Albuquerque, New Mexico: University of New Mexico Press.

Schiffer, MB. 1995. Behavioral archaeology. Salt Lake City, Utah: University of Utah Press.

Shott, MJ. 1986. Settlement mobility and technological organization among Great Lakes Paleo-Indian foragers. Unpublished dissertation (PhD), University of Michigan.

Shott, MJ. 1993. The Leavitt site: A Parkhill Phase PaleoIndian occupation in central Michigan. University of Michigan Museum of Anthropology Memoirs No. 25. Ann Arbor, Michigan: University of Michigan. DOI: https://doi. org/10.3998/mpub.11394830

Shott, MJ. 1996. An exegesis of the curation concept. Journal of Anthropological Research, 52(3): 259-280. DOI: https://doi. org/10.1086/jar.52.3.3630085

Shott, MJ. 2002. Weibull estimation on use life distribution in experimental spear-point data. Lithic Technology, 27(2): 
93-109. DOI: https://doi.org/10.1080/01977261.2002.117 20993

Shott, MJ and Ballenger, JAM. 2007. Biface reduction and the measurement of Dalton curation: A southeastern United States case study. American Antiquity, 72(1): 153-175. DOI: https://doi.org/10.2307/40035302

Shott, MJ and Sillitoe, P. 2004. Modeling use-life distributions in archaeology using New Guinea Wola ethnographic data. American Antiquity, 69(2): 339-355. DOI: https://doi. org/10.2307/4128424

Simons, DB, Shott, MJ and Wright, HT. 1984. The Gainey site: Variability in a Great Lakes Paleo-Indian assemblage. Archaeology of Eastern North America, 12: 266-279. https:// www.jstor.org/stable/40914243

Smallwood, AM, Jennings, TA, Anderson, DG and Ledbetter, J. 2015. Testing for evidence of Paleoindian responses to environmental changes during the Younger Dryas Chronozone in Georgia. Southeastern Archaeology, 34(1): 23-45. DOI: https://doi.org/10.1179/216847231 $4 Y .0000000006$

Speth, JD. 2018. A new look at old assumptions: Paleoindian communal bison hunting, mobility, and stone tool technology. In: Carlson, $\mathrm{K}$ and Bement LC (eds.), The archaeology of large-scale manipulation of prey: The economic and social dynamics of mass hunting, 161-285. Boulder, Colorado: University Press of Colorado. DOI: https:// doi.org/10.2307/j.ctv14h5hs.10

Speth, JD, Newlander, K, White, AA, Lemke, AK and Anderson, LE. 2013. Early Paleoindian big-game hunting in North America: Provisioning or politics? Quaternary International, 285: 111-139. DOI: https://doi.org/10.1016/j. quaint.2010.10.027

Storck, PL. 1997. The Fisher site: Archaeological, geological, and paleobotanical studies at an Early Paleo-Indian site in southern Ontario, Canada. University of Michigan Museum of Anthropology Memoirs No. 30. Ann Arbor, Michigan: University of Michigan. DOI: https://doi.org/10.3998/ mpub.11395063

Tankersley, KB. 1989. Late Pleistocene lithic exploitation and human settlement patterns in the Midwestern United States. Unpublished dissertation (PhD), Indiana University.
Tankersley, KB. 1994. Was Clovis a colonizing population in eastern North America? In: Dancey, WS (ed.), The First Discovery of America, 95-116. Columbus, Ohio: The Ohio Archaeological Council.

Titmus, GL and Woods, JC 1986. An experimental study of projectile point fracture patterns. Journal of California and Great Basin Anthropology, 8(1): 37-49. https://www.jstor. org/stable/27825255

Tomasso, A and Porraz, G. 2016. Hunter-gatherer mobility and embedded raw-material procurement strategies in the Mediterranean Upper Paleolithic. Evolutionary Anthropology, 25: 164-174. DOI: https://doi.org/10.1002/ evan. 21488

Tune, JW. 2016. The Clovis-Cumberland-Dalton succession: Settling into the Midsouth United States during the Pleistocene to Holocene transition. PaleoAmerica. DOI: https://doi.org/10.1080/20555563.2016.1199193

Walthall, JA. 1998. Overwinter strategy and Early Holocene hunter-gatherer mobility in temperate forests. Midcontinental Journal of Archaeology, 23(1): 1-22. https:// www.jstor.org/stable/20708421

Walthall, JA and Koldehoff, B. 1999. Across the divide: Dalton land use in the Southern Till Plains. Illinois Archaeology, 11(1 and 2): 27-49.

White, AA. 2012. The social networks of early hunter-gatherers in midcontinental North America. Unpublished dissertation (PhD), University of Michigan.

White, AA. 2014. Changing scales of lithic raw material transport among early hunter-gatherers in midcontinental North America. Archaeology of Eastern North America, 42: 51-75. https://www.jstor.org/ stable/43868958

White, AA. 2016. A preliminary analysis of haft variability in South Carolina Kirk points. South Carolina Antiquities, 48: 41-53.

White, AA. 2019. A comparison of functional variability among Early Archaic notched points from the Lower Savannah River. South Carolina Antiquities, 51: 1-21.

Wilkinson, JE. 2019. Evaluating Kirk Corner Notched resharpening trajectories through experimental archaeology. South Carolina Antiquities, 51: 61-86. 
TO CITE THIS ARTICLE:

White, A. 2021. Lithic Transport Patterns, Tool Curation Behavior, and Group Range Estimates: A Model-Based Exploration. Journal of Computer Applications in Archaeology, 4(1): 254-273. DOI: https://doi.org/10.5334/jcaa.82

Submitted: 03 August 2021 Accepted: 03 November 2021 Published: 26 November 2021

COPYRIGHT:

(c) 2021 The Author(s). This is an open-access article distributed under the terms of the Creative Commons Attribution 4.0 International License (CC-BY 4.0), which permits unrestricted use, distribution, and reproduction in any medium, provided the original author and source are credited. See http://creativecommons.org/licenses/by/4.0/.

Journal of Computer Applications in Archaeology is a peer-reviewed open access journal published by Ubiquity Press.

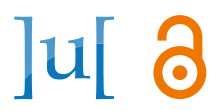

